ISSN: 1858-4837; E-ISSN: 2598-019X

Volume 16, Nomor 2 (2021),

https://jurnal.uns.ac.id/region

DOI: 10.20961/region.v16i2.41907

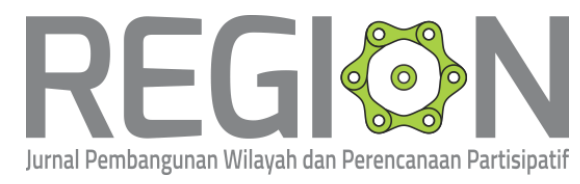

\title{
Indeks aksesibilitas regional Jawa Tengah dan Daerah Istimewa Yogyakarta menggunakan principal component analysis dan kernel density analysis
}

\author{
Measuring Central Java and Special Region of Yogyakarta Regional \\ accessibilities using principal component analysis and kernel density analysis
}

\author{
D A I Lesmana ${ }^{1}$, M S Roychansyah ${ }^{2}$ \\ ${ }^{1}$ Program Studi Magister Perencanaan Wilayah dan Kota, Fakultas Teknik, Universitas \\ Gadjah Mada, Yogyakarta, Indonesia \\ ${ }^{2}$ Departemen Teknik Arsitektur dan Perencanaan, Fakultas Teknik, Universitas \\ Gadjah Mada, Yogyakarta, Indonesia
}

Corresponding author's email: dwi.aditya.i.l@mail.ugm.ac.id

\begin{abstract}
Abstrak. Jawa Tengah dan Daerah Istimewa Yogyakarta merupakan dua provinsi yang memiliki keterkaitan tinggi. Studi-studi sebelumnya menerangkan bahwa keterkaitan itu utamanya adalah keterkaitan ekonomi. Keterkaitan ekonomi tersebut terjadi berkat adanya aksesibilitas regional antara Jawa Tengah dan Daerah Istimewa Yogyakarta. Aksesibilitas regional telah lama diteliti dengan berbagai teknik perhitungan. Seringkali penggunaan teknik-teknik tersebut tidak dapat diaplikasikan secara cepat untuk menghitung dalam skala regional dikarenakan sulitnya memperoleh data yang lengkap sampai unit administratif terkecil. Di sisi lain, telah tersedia data potensi desa yang dipublikasikan secara teratur setiap tiga tahun oleh BPS yang memuat data waktu tempuh dan jarak tempuh sampai level desa. Tujuan penelitian ini adalah mengukur aksesibilitas regional di Jawa Tengah dan Daerah Istimewa Yogyakarta. Metode yang digunakan adalah principal component analysis dan kernel density analysis. Hasil analisis menunjukkan bahwa nilai aksesibilitas regional di Jawa Tengah dan Daerah Istimewa Yogyakarta sebagian besar adalah sedang sampai tinggi. Pada Jawa Tengah dan Daerah Istimewa Yogyakarta terbentuk beberapa kelompok integrasi aksesibilitas regional. Penelitian ini membuktikan dimungkinkannya penggunaan teknik analisis lain untuk menghitung aksesibilitas regional selain daripada teknik-teknik yang sudah diketahui.
\end{abstract}

Kata Kunci: Aksesibilitas Regional; Density Analysis; Keterkaitan Ekonomi; PCA

Received : June 02, 2020; Accepted: July 14, 2020; Available online: July 15, 2021

Copyright @ 2021, REGION: Jurnal Pembangunan Wilayah dan Perencanaan Partisipatif 


\begin{abstract}
Central Java and Special Region of Yogyakarta are two provinces that have high linkages. Previous studies have explained that the primary linkages is economic. The economic linkages occur due to regional accessibility between Central Java and the Special Region of Yogyakarta. Regional accessibility has long been investigated with various calculation techniques. The use of these techniques often cannot be applied quickly to calculate on a regional scale due to the difficulty of obtaining complete data to the smallest administrative unit. On the other hand, village potential data has been available and published regularly every three years by BPS which includes data on travel time and distance to the village scale. The purpose of this study is to measure regional accessibility in Central Java and Special Region of Yogyakarta. The method employed principal component analysis and kernel density analysis. The analysis shows that the value of regional accessibility in Central Java and Special Region of Yogyakarta is mostly moderate to high. In Central Java and Special Region of Yogyakarta, several regional accessibility integration groups were formed. This study proves the possibility of using other analytical techniques to calculate regional accessibility.
\end{abstract}

Keywords: Density Analysis; Economic Linkages; PCA; Regional Accessibility

\title{
1. Pendahuluan
}

Provinsi Jawa Tengah dan Daerah Istimewa Yogyakarta memiliki keterkaitan tinggi khususnya dalam bidang ekonomi [1]. Keterkaitan antara kedua provinsi ini dipelajari oleh peneliti sejak dahulu sampai saat ini. Pada 1980, Rutz menyatakan bahwa kota-kota di kedua provinsi ini saling mempengaruhi [2]. Dalam laporan Rutz, dicirikan dengan arah pengaruh kota-kota yang diteliti olehnya menggunakan teori tempat pusat Christaller. Disebutkan oleh Rutz pada 1980 di Jawa Tengah dan Daerah Istimewa Yogyakarta, hanya Kota Semarang yang menduduki posisi metropolis regional, diikuti oleh Kota Yogyakarta pada pusat orde tinggi dengan sebagian fungsi metropolis, dan Kota Surakarta, Kota Purwokerto, Kota Magelang, serta Kota Tegal berada pada level pusat orde tinggi dengan sangat sedikit fungsi metropolis [2].

Rutz menyebut pengaruh Kota Semarang sampai ke Magelang, Salatiga, Kudus, dan Pati, pengaruh Kota Yogyakarta sampai ke Gombong bagian barat dan Klaten bagian timur, sedangkan pengaruh Kota Surakarta sampai Pacitan dan Boyolali [2]. Rutz berpendapat salah satu faktor utama yang mempengaruhi adalah kondisi transportasi wilayah yang dalam studinya menggunakan ukuran ketersediaan fasilitas, volume transfer, dan jumlah simpangan jalan utama [2].

Pada 2008, Wibowo melakukan pemodelan keterkaitan ekonomi antara Jawa Tengah dan Daerah Istimewa Yogyakarta. Berdasarkan hasil penelitiannya terdapat 22 kabupaten kota yang memiliki keterkaitan tinggi berdasarkan aliran barang masuk dan keluar di Jawa Tengah dan Daerah Istimewa Yogyakarta. Kabupaten kota itu menurut penelitian Wibowo adalah Purworejo, Wonosobo, Magelang, Boyolali, Klaten, Sukoharjo, Karanganyar, Sragen, Grobogan, Blora, Demak, Semarang, Temanggung, Kota Magelang, Kota Surakarta, Kota 
Salatiga, Kota Semarang, Kulon Progo, Bantul, Gunung Kidul, Sleman dan Kota Yogyakarta [1]. Meskipun Wibowo menyebut adanya keterkaitan ekonomi tinggi, tetapi Wibowo tidak melakukan analisis fasilitas transportasi dalam penelitiannya, sehingga aksesibilitas regional yang diduga berpengaruh terhadap keterkaitan ekonomi tersebut tidak secara jelas terpotret.

Dalam mengukur aksesibilitas wilayah, telah ditemukan beberapa formula oleh penelitianpenelitian terdahulu. Formula-formula tersebut disusun berdasarkan variabel-variabel yang secara garis besar dapat dikelompokkan oleh tiga variabel utama. Variabel yang mempengaruhi aksesibilitas regional adalah pusat aktivitas atau guna lahan $[3,4]$, infrastruktur transportasi [4,5], dan kinerja transportasi $[5,6]$.

Formula-formula aksesibilitas yang disusun oleh penelitian-penelitian terdahulu, umumnya didesain untuk mengukur aksesibilitas kota atau beberapa kota saja. Seperti formula indeks beta Kansky yang mensyaratkan adanya jumlah satuan simpul permukiman dan jumlah jaringan transportasi yang menghubungkannya [7]. Indeks detour dan sub graph memerlukan data panjang jalan [8]. Penggunaan data panjang jalan per administratif wilayah masih relevan dilakukan jika skala yang digunakan adalah skala kabupaten kota, akan tetapi jika target analisis adalah skala regional dengan detail tingkat kecamatan untuk dua provinsi maka penggunaan panjang jalan dan simpul permukiman menjadi sangat kompleks dan rumit.

Rumitnya perhitungan aksesibilitas wilayah menjadikan perhitungan aksesibilitas hanya dilakukan pada tingkat kabupaten atau kota. Sementara itu, terdapat kebutuhan untuk menjawab pertanyaan seberapa tingkat aksesibilitas regional dalam skala yang lebih luas. Seperti kondisi Jawa Tengah dan Daerah Istimewa Yogyakarta yang diduga memiliki keterkaitan tinggi dalam hal ekonomi karena pengaruh aksesibilitasnya $[1,9,10]$. Oleh sebab itu, penelitian ini bertujuan untuk mengukur aksesibilitas regional di Jawa Tengah dan Daerah Istimewa Yogyakarta.

\section{Metode}

Metode yang digunakan dalam penelitian ini adalah metode kuantitatif. Metode ini dipakai setelah sebelumnya dilakukan deduksi terhadap variabel-variabel yang diduga kuat mempengaruhi tingkat aksesibilitas regional. Secara umum, proses analisis penelitian aksesibilitas regional dapat dilihat pada Gambar 1 berikut.

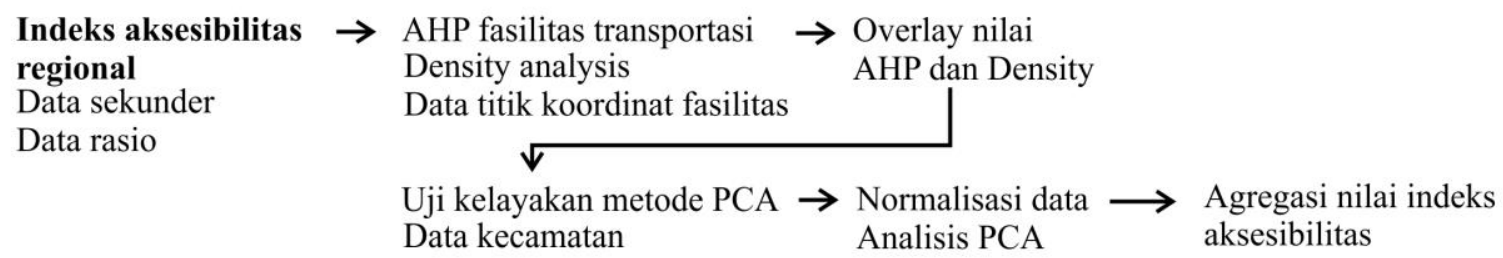

Gambar 1. Proses analisis penelitian. 
Proses untuk mendapatkan hasil indeks aksesibilitas regional diawali dengan melakukan pembobotan menggunakan AHP (Analytic Hierarchy Process) dan analisis spasial density analysis. Tujuan dari proses ini adalah mengolah data koordinat atau jenis data nominal menjadi jenis data rasio. Proses ini penting mengingat jenis data nominal tidak dapat digunakan dalam proses analisis principal component analysis. Oleh sebab itu, diperlukan data yang berjenis rasio. Setelah dilakukan pembobotan menggunakan AHP dan masingmasing koordinat terbobot telah dilakukan density analysis, maka dilakukan uji kelayakan metode PCA. PCA mensyaratkan adanya korelasi antar variabel-variabelnya, uji statistik yang bisa digunakan adalah uji KMO (Kaiser-Meyer-Olkin) dan bartlett's test of sphericity. Proses dilanjutkan dengan melakukan normalisasi data dan terakhir melakukan agregasi nilai untuk mendapatkan nilai aksesibilitas regional.

\subsection{Data dan indikator penelitian}

Seperti dijelaskan pada bagian pendahuluan, penelitian ini bertujuan untuk mengukur aksesibilitas regional di Jawa Tengah dan Daerah Istimewa Yogyakarta. Pengukuran aksesibilitas tersebut dilakukan pada tingkat ketelitian kecamatan, sehingga perlu metode yang sederhana dan dapat diaplikasikan secara cepat. Oleh sebab itu, indikator-indikator yang diterangkan sebelumnya di bagian pendahuluan dipilih diwakilkan hanya pada datadata yang dapat tersedia pada level kecamatan. Total kecamatan sejumlah 651. Data pada penelitian ini adalah data tahun 2018. Secara lebih jelas dapat dilihat pada Tabel 1.

Tabel 1. Indikator penelitian.

\begin{tabular}{lll}
\hline \multicolumn{1}{c}{ Jenis } & \multicolumn{1}{c}{ Satuan } & \multicolumn{1}{c}{ Sumber data } \\
\hline Fasilitas transportasi & Unit & $\begin{array}{l}\text { Dinas Perhubungan, PT. } \\
\text { Kereta Api }\end{array}$ \\
Guna lahan & Persentase & $\begin{array}{l}\text { Bappeda, DPUTR, Digitasi } \\
\text { Waktu tempuh }\end{array}$ \\
Jarak tempuh & Kenit & BPS \\
\hline
\end{tabular}

\subsection{Analytic Hierarchy Process (AHP)}

Teknik analytic hierarchy process selanjutnya disebut AHP pada penelitian ini digunakan untuk menentukan bobot masing-masing fasilitas transportasi dan tidak sampai tahap pemilihan alternatif. Pembobotan dilakukan dengan menggunakan AHP karena bobot fasilitas transportasi yang diberikan atas pertimbangan subyektif peneliti. Diagram hirarki fasilitas transportasi sebagaimana terlihat pada Gambar 2.

Dalam pertimbangannya peneliti mendasarkan pada telaah literatur mengenai tingkat kepentingan masing-masing fasilitas. Jenis fasilitas yang diikutkan dalam analisis adalah fasilitas terminal, stasiun kereta api, pelabuhan dan bandar udara. Bobot dalam AHP diperoleh dengan melakukan pairwise comparison berdasarkan tingkat kepentingan [11]. Saaty [12]memberi pedoman untuk penskalaan sebagaimana pada Tabel 2. 


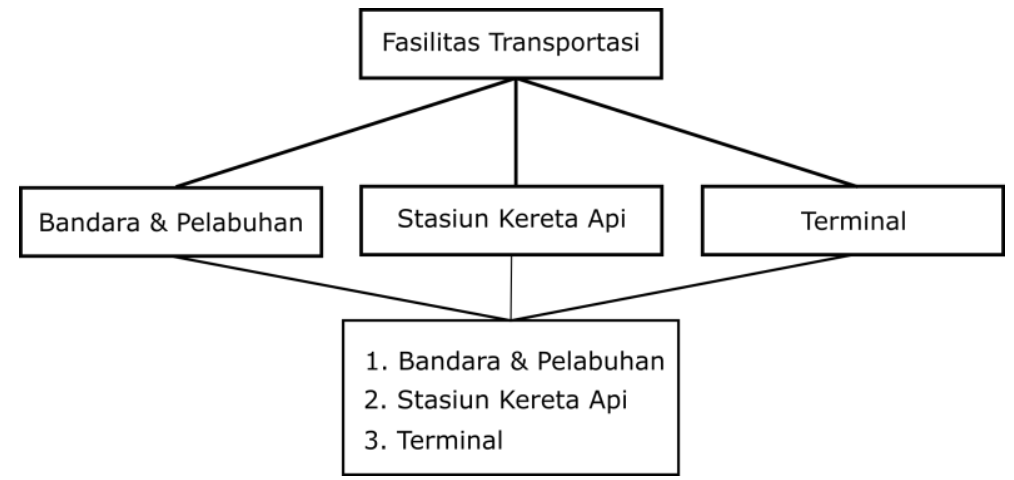

Gambar 2. Diagram AHP fasilitas transportasi [12].

Koordinat fasilitas transportasi dibobot dengan pedoman, semakin tinggi ambang dan jangkauan fasilitas semakin tinggi bobot fasilitas tersebut. Salah satu ciri fasilitas dengan ambang (threshold) dan jangkauan (range) besar adalah tersedia dalam jumlah kecil dan terbatas [7]. Jadi bobot tertinggi fasilitas transportasi sesuai urutan adalah (1) bandar udara dan pelabuhan internasional, (2) stasiun kereta api, (3) terminal.

Tabel 2. Intensitas kepentingan pairwise comparison [11].

\begin{tabular}{cl}
\hline $\begin{array}{c}\text { Intensitas kepentingan skala } \\
\text { absolut }\end{array}$ & \multicolumn{1}{c}{ Definisi } \\
\hline $\mathbf{1}$ & Sama penting \\
$\mathbf{3}$ & Sedikit penting \\
$\mathbf{5}$ & Lebih penting \\
$\mathbf{7}$ & Sangat lebih penting \\
$\mathbf{9}$ & Mutlak lebih penting \\
$\mathbf{2 , 4 , 6 , 8}$ & Nilai di antara nilai absolut \\
\hline
\end{tabular}

Menurut Saaty proses pemberian bobot harus diuji untuk menilai konsistensi peneliti dalam pemberian bobot. Uji konsistensi tersebut meliputi (a) lamda max, (b) consistency index, (c) consistency ratio, nilai consistency ratio $\leq 0.1$ menurut Saaty menunjukkan bahwa penilaian yang dilakukan menggunakan metode AHP dapat dipercaya [11].

\subsection{Density analysis}

Density analysis atau analisis kepadatan menunjukkan besarnya magnitude per area unit dalam suatu wilayah [13]. Analisis densitas mampu menunjukkan tingkat konsentrasi suatu fitur dalam wilayah [13]. Pada penelitian ini digunakan kernel density untuk menghitung tingkat konsentrasi fasilitas transportasi di wilayah. Kernel density dipilih karena menghasilkan output dengan garis lengkung yang lebih halus dan generalisasi nilai sekitar poin utama. Nilai piksel tertinggi adalah pada poin utama dan menurun saat menjauhi pusat poin utama sampai akhirnya menghilang saat mencapai angka 0 [13]. Contoh analisis densitas seperti pada Gambar 3. 


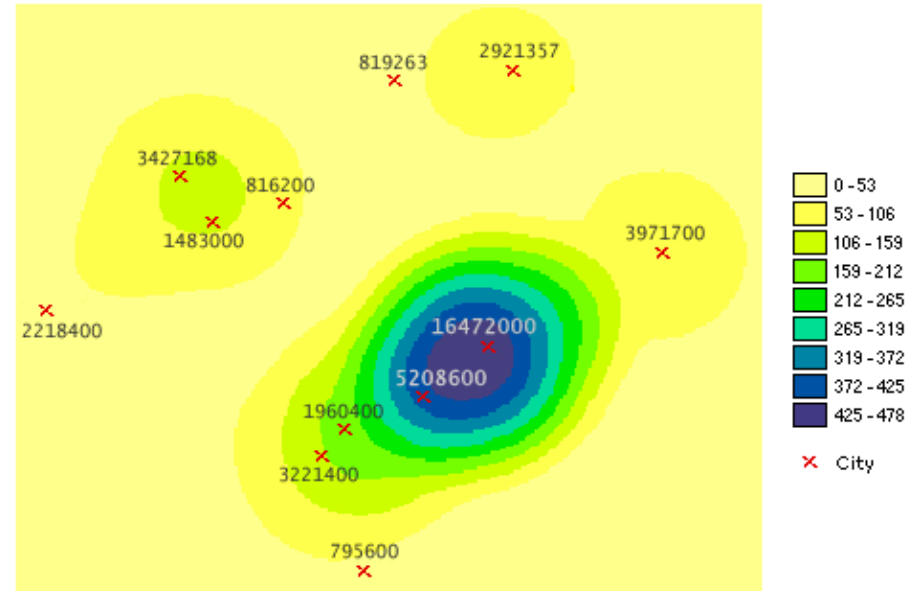

Gambar 3. Contoh density analysis [13].

Bobot yang diperoleh dari hasil analisis AHP kemudian dikalikan dengan nilai piksel dari analisis densitas. Proses perkalian ini dilakukan per masing-masing unit fasilitas transportasi. Setelah masing-masing fasilitas sudah dilakukan perkalian AHP dan densitas maka dilakukan penampalan peta (overlay). Penampalan ini menghasilkan peta raster dengan wilayah yang berada di sekitar fasilitas yang paling lengkap memiliki nilai piksel tertinggi, sedangkan wilayah yang jauh dari fasilitas transportasi mendapatkan nilai piksel rendah. Setelah diketahui nilai per masing-masing piksel, maka dilakukan ekstraksi nilai fasilitas transportasi per masing-masing kecamatan.

\subsection{Principal component analysis (PCA)}

Analisis PCA merupakan suatu analisis yang termasuk dalam kelompok analisis reduksi data [14]. Analisis PCA mampu menjelaskan variansi penuh dari data faktor matriknya, berbeda dengan analisis faktor yang hanya mampu menjelaskan common variance dalam faktor matriksnya [15]. Pada penelitian ini analisis PCA dilakukan dengan mengikuti beberapa proses di antaranya (1) normalisasi data, (2) uji bartlett's test of sphericity dan KMO (KaiserMeyer-Olkin), (3) menghitung nilai eigen value, percentage of variance, dan factor loading.

Pada penelitian ini dilakukan normalisasi data untuk meminimalisir bias data karena adanya perbedaan satuan data. Metode normalisasi data pada penelitian ini adalah normalisasi data z score, yaitu rata-rata data nol dan deviasinya satu [16]. Formula normalisasi data z score yang diadaptasi dari OECD sebagai berikut.

$$
I_{q c}^{t}=\left(x_{q c}^{t}-\bar{x}_{q}^{t}\right) / \sigma_{q}^{t}
$$

$I_{a c}^{t}=$ nilai variabel terstandar q pada kota/kecamatan c pada waktu $\mathrm{t}$

$x_{q c}^{t}=$ nilai variabel q pada kota/kecamatan c pada waktu $\mathrm{t}$

$\bar{x}_{q}^{t}=$ nilai rata-rata variabel q seluruh kota/kecamatan pada waktu $\mathrm{t}$

$\sigma_{a}^{t}=$ nilai standar deviasi variabel q seluruh kota/kecamatan

Uji bartlett's test of sphericity digunakan untuk menguji apakah matriks korelasi adalah matrik identitas, dengan nilai satu pada diagonal pokoknya dan nol di luar diagonal 
pokoknya [14]. Uji bartlett's test of sphericity menggunakan pendekatan nilai chi-square [14]. Uji KMO digunakan untuk menguji apakah korelasi parsial kecil dengan membandingkan nilai koefisien korelasi terobservasi dengan nilai korelasi parsial [14]. Nilai KMO $\geq 0,6$ menurut Gudono sudah memenuhi syarat.

Penentuan eigenvalue dan percentage of variance pada penelitian ini menggunakan kriteria minimal $70 \%$ varian terjelaskan, hal ini sesuai pendapat Gudono bahwa ekstraksi di atas $60 \%$ sudah bagus [14]. Besaran factor loading atau dalam istilah lain eigen vector komponen yang diambil adalah minimal 0,3 [14].

\subsection{Formula indeks aksesibilitas regional}

Formula indeks aksesibilitas regional pada penelitian ini menggunakan analogi formula indeks pengaruh kota yang disusun Wang dkk [6]. Wang dkk menyusun suatu formula yang dapat digunakan untuk mengukur pengaruh kota berdasarkan komposit pelbagai indikator perkotaan dengan memanfaatkan hasil analisis PCA, yaitu dengan memanfaatkan nilai besaran kontribusi komponen, nilai factor loading, dan nilai variabel yang telah distandarkan [6]. Jadi formula aksesibilitas regional pada penelitian ini adalah sebagai berikut.

$$
\begin{aligned}
& \qquad A R=\sum_{n=1}^{m}\left[D n x \sum_{j=1}^{4} E n j \times F k j\right] \\
& A R=\text { aksesibilitas regional } \\
& \text { Dn = tingkat kontribusi dari principal component ke } \mathrm{n} \\
& \mathrm{Enj}=\text { nilai loading ke } \mathrm{n} \text { dari principal component variabel } \mathrm{j} \\
& \mathrm{Fkj}=\text { variabel yang distandarkan }
\end{aligned}
$$

\section{Hasil dan pembahasan}

\subsection{Hasil AHP dan density analysis}

Seperti dijelaskan pada bagian metode, skor kepentingan AHP diberikan sesuai prinsip ambang dan jangkauan fasilitas transportasi. Fasilitas transportasi bandara dan pelabuhan memiliki intensitas kepentingan tertinggi karena sebagai hub internasional, dan fasilitas terminal memiliki intensitas kepentingan terendah karena ambang dan jangkauannya paling rendah. Tabel 3 menunjukkan intensitas kepentingan fasilitas transportasi.

Tabel 3. Intensitas kepentingan fasilitas transportasi.

\begin{tabular}{cccc}
\hline AHP & $\begin{array}{c}\text { Bandara \& } \\
\text { Pelabuhan }\end{array}$ & Stasiun & Terminal \\
\hline Bandara \& Pelabuhan & 1,000 & 3,000 & 5,000 \\
Stasiun & 0,333 & 1,000 & 3,000 \\
Terminal & 0,200 & 0,333 & 1,000 \\
\hline
\end{tabular}

Hasil analisis AHP sebagaimana pada Tabel 4 menunjukkan fasilitas transportasi bandara dan pelabuhan memiliki vektor prioritas 0,633 , untuk fasilitas stasiun kereta api memiliki vektor prioritas 0,260 , dan terakhir untuk fasilitas terminal memiliki vektor prioritas 0,106 . Dalam metode AHP, Saaty [12] memberi pedoman batasan tertentu nilai consistency ratio yakni 
kurang dari 0,1. Nilai consistency ratio (CR) didapatkan dengan membandingkan nilai consistency index peneliti terhadap consistency index dari random-like matrix (RI).

Pada penelitian ini, consistency ratio (CR) fasilitas transportasi bernilai 0,029 yang kurang dari 0.1 , yang berarti memenuhi kriteria Saaty. Hasil perhitungan menunjukkan lamda sebesar 3,039, consistency index sebesar 0,019, dan random-like matrix (RI) sebesar 0,660 pada $n=3$. Bobot AHP kemudian dikali dengan nilai kernel density analysis menggunakan raster calculator ArcGIS 10.3 dan menghasilkan Gambar 4.

Tabel 4. Priority vector fasilitas transportasi.

\begin{tabular}{cc}
\hline Variabel & Priority Vector \\
\hline Bandara \& Pelabuhan & 0,633 \\
Stasiun & 0,260 \\
Terminal & 0,106 \\
\hline
\end{tabular}

Nilai piksel fasilitas transportasi menghasilkan nilai terendah 0 dan tertinggi 25,19, dengan nilai rata-rata 7,41 dan standar deviasi 5,63. Nilai piksel fasilitas transportasi kemudian diekstrak per masing-masing kecamatan menggunakan interpolasi bilinear, yakni nilai fasilitas transportasi kecamatan diwakili piksel-piksel yang dekat dengan titik ibukota kecamatan. Interpolasi bilinear menghasilkan nilai fasilitas transportasi terendah sebesar 0,0008 , tertinggi sebesar 26,9 dengan rata-rata sebesar 10,1.

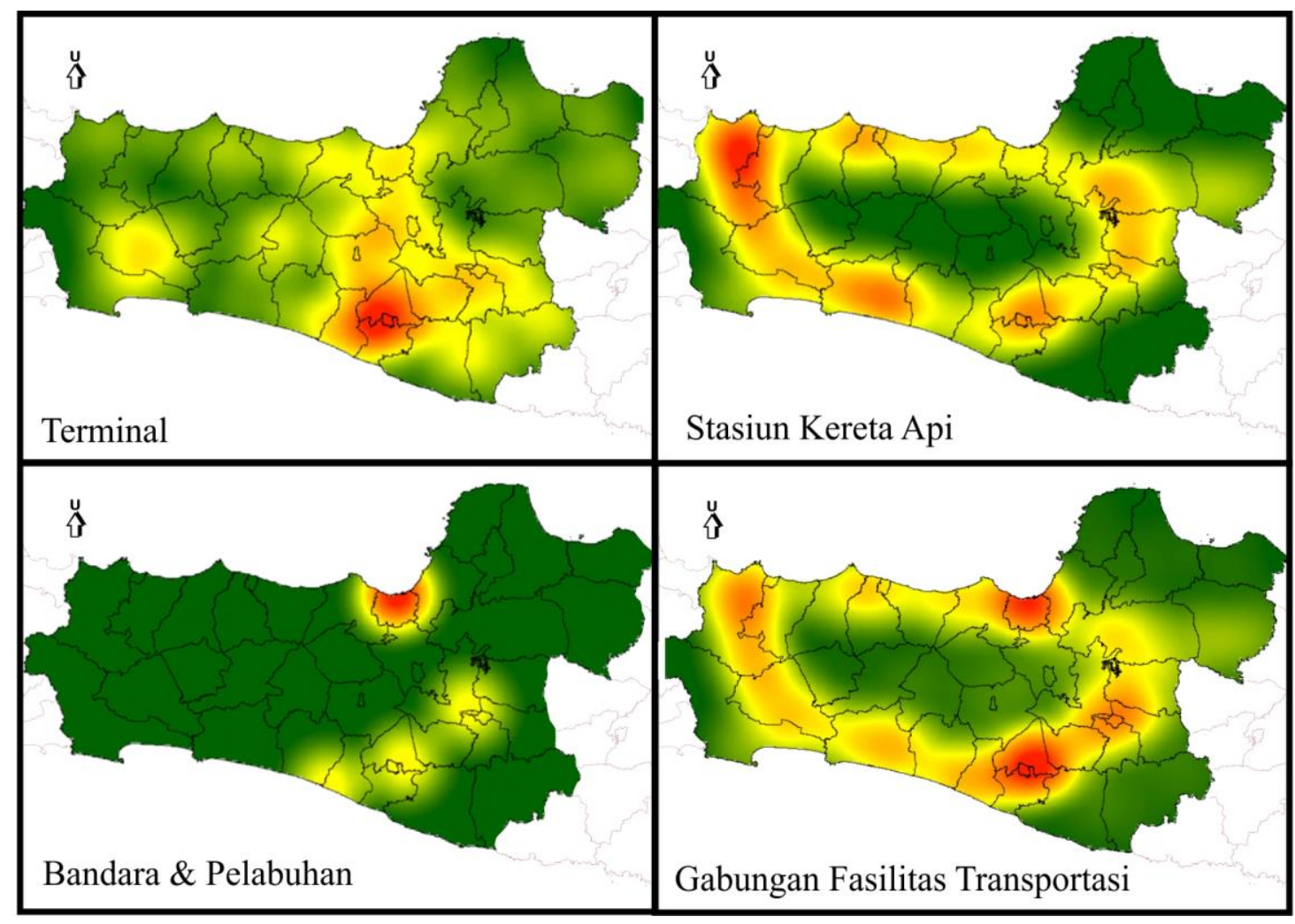

Gambar 4. Overlay AHP dan density fasilitas transportasi. 
Gabungan AHP dan density fasilitas transportasi menghasilkan peta sebaran transportasi yang secara sekilas mirip dengan hasil stasiun kereta api. Peta gabungan fasilitas transportasi menunjukkan secara regional terbentuk integrasi transportasi melingkari sepanjang Jawa Tengah dan Daerah Istimewa Yogyakarta. Peta tersebut juga menggambarkan bahwa terdapat wilayah-wilayah dengan infrastruktur transportasi yang lebih baik dibanding wilayah lainnya, yakni area Kota Yogyakarta dan area Kota Semarang.

\subsection{Hasil PCA}

Penggunaan PCA sebagaimana dijelaskan dalam bagian metode, perlu memenuhi beberapa syarat, di antaranya adalah variabel-variabel yang digunakan harus memiliki korelasi, korelasi populasi bukan merupakan matriks identitas dan perlu memenuhi kecukupan sampel. Pada penelitian ini, keempat variabel aksesibilitas regional 2018 memiliki korelasi yang tinggi $>0,5$ terlihat pada Tabel 5, variabel fasilitas transportasi berkorelasi tinggi dengan variabel guna lahan yakni sebesar 0,59, sedangkan variabel waktu tempuh berkorelasi tinggi dengan variabel jarak tempuh sebesar 0,87 .

Tabel 5. Matriks korelasi aksesibilitas 2018.

\begin{tabular}{cllll}
\hline Variabel & \multicolumn{1}{c}{$\begin{array}{c}\text { Fas. } \\
\text { Transportasi }\end{array}$} & $\begin{array}{c}\text { Guna } \\
\text { lahan }\end{array}$ & $\begin{array}{c}\text { Waktu } \\
\text { tempuh }\end{array}$ & $\begin{array}{c}\text { Jarak } \\
\text { tempuh }\end{array}$ \\
\hline Fas. Transportasi & 1 & & & \\
Guna lahan & 0,5941 & 1 & & \\
Waktu tempuh & 0,2634 & 0,3838 & 1 & \\
Jarak tempuh & 0,3044 & 0,4306 & 0,8733 & 1 \\
\hline
\end{tabular}

Uji bartlett's test of sphericity menunjukkan bahwa seluruh data aksesibilitas regional pada tahun 2018 signifikan pada tingkat alpha 0,05, dilihat dari nilai chi-square $1350>$ tabel $\chi^{2} 0.05(6)=12.59$. Hasil ini menunjukkan bahwa hipotesis bahwa korelasi populasi merupakan matriks identitas ditolak pada alpha 0,05. Uji Kaiser-Meyer-Olkin (KMO) menunjukkan nilai $0,608 \geq 0,6$ sehingga memenuhi persyaratan kecukupan sampel. Dengan demikian, beberapa pertimbangan sebelumnya menunjukkan bahwa analisis PCA dapat dilanjutkan.

Tabel 6. Eigenvalue dan kumulatif PCA tanpa rotasi.

\begin{tabular}{crrrr}
\hline Komponen & Eigenvalue & Perbedaan & Proporsi & \multicolumn{1}{c}{ Kumulatif } \\
\hline Comp1 & 2,44357 & 1,40409 & 0,6109 & 0,6109 \\
Comp2 & 1,03948 & 0,647517 & 0,2599 & 0,8708 \\
Comp3 & 0,39196 & 0,26696 & 0,098 & 0,9688 \\
Comp4 & 0,12499 &. & 0,0312 & 1 \\
\hline
\end{tabular}

Analisis PCA pada Tabel 6 menunjukkan bahwa dua komponen mampu menjelaskan varian data sampai $87 \%$. Menurut Gudono, kumulatif varian yang terjelaskan sebaiknya minimal adalah $60 \%$, dengan nilai loading minimal sebesar 0,3 [13]. Dilihat dari eigenvalue hanya dua komponen yang memiliki nilai eigen lebih dari satu sehingga analisis PCA diekstraksi menggunakan dua komponen saja. Komponen kesatu mampu menjelaskan varian data sampai $61 \%$, sedangkan komponen kedua mampu menjelaskan sampai $26 \%$. 
Tabel 7. Eigenvector atau loading PCA tanpa rotasi.

\begin{tabular}{cccc}
\hline Komponen & Comp1 & Comp2 & Tak terjelaskan \\
\hline Fas. Transportasi & 0.4128 & $\mathbf{0 . 6 3 1 7}$ & 0.1687 \\
Guna lahan & $\mathbf{0 . 4 7 9 1}$ & 0.4607 & 0.2184 \\
Waktu tempuh & $\mathbf{0 . 5 3 9 2}$ & -0.466 & 0.0639 \\
Jarak tempuh & $\mathbf{0 . 5 5 6 1}$ & -0.4141 & 0.06601 \\
\hline
\end{tabular}

Nilai loading komponen satu menunjukkan seluruhnya di atas 0,3. Pada perhitungan indeks aksesibilitas regional yang digunakan adalah nilai tertinggi dari dua komponen yang mewakili. Menurut OECD, bobot untuk indeks komposit dari loading PCA diambil yang tertinggi [16]. Dengan demikian, berdasar Tabel 7 bobot fasilitas transportasi untuk indeks aksesibilitas regional dari loading adalah 0,6317, bobot guna lahan adalah 0,4791, bobot waktu tempuh adalah 0,5392, dan bobot untuk jarak tempuh adalah 0,5561. Dengan dua komponen ini besaran varian tak terjelaskan dari fasilitas transportasi adalah $17 \%$, guna lahan $22 \%$, waktu tempuh $6 \%$, dan jarak tempuh $6 \%$. Bobot masing-masing variabel ini kemudian digunakan untuk menghitung nilai aksesibilitas regional per masing-masing kecamatan sesuai formula 2 pada bagian 2.5 .

\subsection{Indeks aksesibilitas regional Jawa Tengah dan DIY}

Indeks aksesibilitas regional pada penelitian ini dihitung menggunakan formula yang dikembangkan dari analogi formula Wang dkk untuk menghitung indeks pengaruh kota di Central China. Formula indeks aksesibilitas regional penelitian ini menggunakan formula yang dibangun dari komposit indikator dengan bobot dari loading PCA, sebagaimana dijelaskan pada bagian metode 2.5. Hasil perhitungan aksesibilitas regional kemudian dikelompokkan menjadi lima kelas menggunakan kriteria pengelompokkan natural break. Menurut De Smith dkk, pengelompokkan tersebut mampu meminimalkan varians dan kelaskelas dipilih saat nilai mengalami perubahan besar [17]. Hasil aksesibilitas regional Jawa Tengah dan DIY sebagaimana pada Gambar 5. 


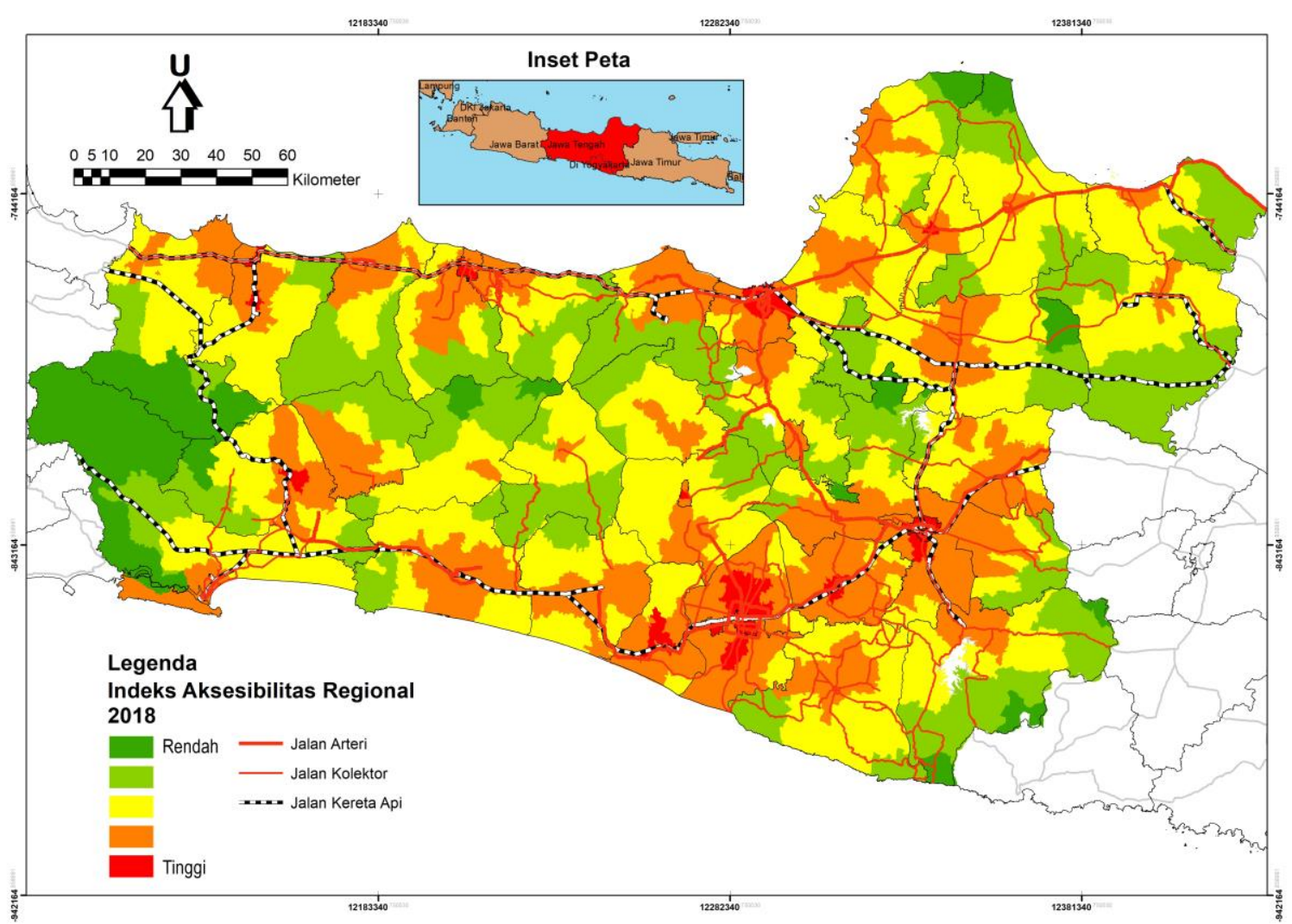

Gambar 5. Peta aksesibilitas regional Jawa Tengah dan DIY 2018.

Pada 2018, berdasarkan analisis aksesibilitas regional menggunakan PCA dan density analysis, terlihat ada pengelompokkan aksesibilitas regional antara wilayah utara dan selatan. Terlihat, terjadi integrasi aksesibilitas regional yang kuat atau tinggi pada Kota Yogyakarta, Kabupaten Sleman, dan Kabupaten Bantul, demikian pula yang teramati pada Kota Surakarta dengan Kartasura Kabupaten Sukoharjo. Dari keseluruhan 14 kabupaten kota yang memiliki nilai aksesibilitas tinggi atau kategori V, 4 (empat) terdapat di Daerah Istimewa Yogyakarta, dan 10 (sepuluh) terdapat di Jawa Tengah. Masing-masing adalah Kota Yogyakarta, Kabupaten Sleman, Kabupaten Bantul, dan Kabupaten Kulon Progo di DIY, kemudian Kota Semarang, Kota Surakarta, Kota Tegal, Kota Pekalongan, Kota Magelang, Kabupaten Tegal, Kabupaten Kudus, Kabupaten Sukoharjo, Kabupaten Klaten, dan Kabupaten Banyumas di Jawa Tengah. Detail aksesibilitas regional per total kecamatan dapat dilihat pada Tabel 8.

Tabel 8. Kategori aksesibilitas regional 2018.

\begin{tabular}{cc}
\hline Kategori & Jumlah Kecamatan \\
\hline I (rendah) & 26 \\
II (cukup rendah) & 125 \\
III (sedang) & 226 \\
IV (cukup tinggi) & 224 \\
V (tinggi) & 50 \\
\hline
\end{tabular}


Secara keseluruhan berdasarkan analisis, mayoritas aksesibilitas regional di Jawa Tengah dan DIY cukup baik, sebab kategori mayoritas adalah pada kategori sedang sampai tinggi, yakni sebesar 76,8 persen. Nilai aksesibilitas tertinggi adalah 6,54, dengan terendah -1,28 dan nilai tengah 4,39. Bila dilihat dari sebarannya maka kategori aksesibilitas yang ada membentuk pola integrasi antarkota. Integrasi ini utamanya terlihat dari sepanjang jalur transportasi utama baik itu jalan arteri, jalan kolektor dan jalur kereta api. Pada Gambar 5 teramati ada lima kelompok besar integrasi aksesibilitas regional tersebut.

Kelompok integrasi aksesibilitas regional yang pertama adalah Jawa Tengah-DIY, yakni integrasi yang membentang lintas provinsi. Pada kategori pertama ini meliputi Kabupaten Sragen, Kabupaten Karanganyar, Kota Surakarta, Kabupaten Sukoharjo, Kabupaten Boyolali, Kabupaten Wonogiri, Kabupaten Klaten, Kabupaten Sleman, Kota Yogyakarta, Kabupaten Bantul, Kabupaten Gunung Kidul, Kabupaten Kulon Progo, Kabupaten Magelang, Kota Magelang, Kabupaten Temanggung, Kabupaten Purworejo, dan Kabupaten Kebumen.

Kelompok integrasi kedua meliputi Kota Semarang, Kabupaten Kendal, Kabupaten Semarang, Kota Salatiga, Kabupaten Demak, Kabupaten Jepara, Kabupaten Kudus, Kabupaten Grobogan, Kabupaten Pati, Kabupaten Rembang, dan Kabupaten Blora. Untuk kelompok ketiga meliputi Kabupaten Purbalingga, Kabupaten Banyumas, dan Kabupaten Cilacap. Kelompok keempat meliputi Kota Tegal, Kabupaten Tegal, dan Kabupaten Brebes. Kelompok kelima meliputi Kota Pekalongan, Kabupaten Pekalongan, Kabupaten Batang, dan Kabupaten Pemalang.

Hasil analisis aksesibilitas regional penelitian ini memperkuat temuan penelitian Rutz dan Wibowo, bahwa terjadi keterkaitan tertentu dan klaster-klaster integrasi di Jawa Tengah dan Daerah Istimewa Yogyakarta. Namun demikian, penelitian ini mengindikasikan bahwa pengaruh kota tidak selalu berbanding lurus terhadap tingkat aksesibilitas regionalnya. Pada penelitian Rutz [2], Kota Semarang merupakan kota dengan pengaruh tertinggi di Jawa Tengah dan DIY, akan tetapi pada penelitian ini menunjukkan bahwa tingkat aksesibilitas regional tinggi justru terdapat pada perkotaan Yogyakarta.

Penelitian ini juga menajamkan temuan Wibowo, yang menyatakan bahwa terdapat keterkaitan ekonomi tinggi di Jawa Tengah dan DIY dan sektor-sektor non pertanian memusat di daerah perkotaan. Pada penelitian ini ditajamkan dengan keterkaitan yang Wibowo maksud tersebut terindikasi utamanya terjadi pada sepanjang koridor Kota Yogyakarta dan Kota Surakarta, mengingat tingginya tingkat aksesibilitas regional pada koridor tersebut.

Pada penelitian aksesibilitas regional ini terdapat fenomena wilayah-wilayah yang cenderung jauh dari pusat ibukota kabupaten atau kota, menunjukkan nilai aksesibilitas regional rendah. Hal ini mungkin saja disebabkan karena data yang digunakan pada penelitian ini diperoleh dari BPS, sedang BPS hanya mengukur jarak dan waktu tempuh menuju pusat kota ibukota kabupaten atau kota. Sehingga pusat-pusat ekonomi yang bukan merupakan pusat ibukota kabupaten atau kota, tidak masuk ukuran yang tercakup dalam penelitian ini. Pada 
penelitian selanjutnya, dapat dipertimbangkan oleh peneliti apakah pusat pelayanan ekonomi lebih utama daripada pusat pelayanan publik yang biasanya terdapat di ibukota kabupaten kota, jika saja terdapat lebih dari satu pusat ekonomi di suatu wilayah.

\section{Kesimpulan}

Tingkat aksesibilitas regional di Jawa Tengah dan Daerah Istimewa Yogyakarta pada 2018 cukup tinggi. Hal ini ditunjukkan dengan mayoritas nilai indeks aksesibilitas regional di Jawa Tengah dan Daerah Istimewa Yogyakarta yaitu 76,8\% adalah kategori sedang sampai tinggi. Koridor aksesibilitas regional terlihat di beberapa wilayah, dengan koridor kategori tinggi terbesar adalah koridor Kota Yogyakarta sampai Kota Surakarta. Penelitian aksesibilitas regional ini juga menawarkan suatu metode PCA dan density analysis untuk mengukur aksesibilitas regional secara cepat dengan tingkat ketelitian sampai level kecamatan tanpa harus melakukan ekstraksi panjang jalan, luas jalan, dan simpul-simpul jalan yang biasanya merupakan prasyarat pada penggunaan metode-metode pengukuran aksesibilitas sebelumnya, yang amat sulit dan rumit jika dilakukan dalam ruang lingkup regional antar provinsi. Penelitian selanjutnya perlu memperbanyak kinerja transportasi mengingat pada penelitian ini cenderung mengukur dari segi infrastruktur transportasi, hanya waktu tempuh yang dapat dikatakan sebagai kinerja transportasi. Selain itu penelitian selanjutnya perlu mempertimbangkan keberadaan pusat-pusat ekonomi lain jika memang di suatu wilayah terdapat lebih dari satu pusat ekonomi. Penelitian selanjutnya dapat mempergunakan data guna lahan yang lebih detail mengingat pada penelitian ini hanya menggunakan data persentase guna lahan area terbangun.

\section{Pernyataan}

Paper ini merupakan bagian dari tesis program pascasarjana FT UGM yang berjudul pengembangan improved field model bagi aglomerasi perkotaan di Jawa Tengah dan Daerah Istimewa Yogyakarta.

\section{Referensi}

[1] Wibowo AA. Model pembangunan ekonomi daerah berbasis kawasan kerjasama strategis joglosemar (Jogjakarta-Solo-Semarang). Institut Pertanian Bogor, 2008.

[2] Rutz W. Cities and towns in Indonesia. Stuttgart: Gebruder Borntraeger; 1987.

[3] Martens K. Transport Justice. London: Routledge; 2017.

[4] Merlin LA, Levine J, Grengs J. Accessibility analysis for transportation projects and plans. Transp Policy 2018;69:35-48. https://doi.org/10.1016/j.tranpol.2018.05.014.

[5] Duran-Fernandez R, Santos G. A regional model of road accessibility in Mexico: Accessibility surfaces and robustness analysis. Res Transp Econ 2014;46:55-69. https://doi.org/10.1016/j.retrec.2014.09.005.

[6] Wang L, Deng Y, Shenghe L, Wang J. Research on urban spheres of influence based on improved field model in central China. J Geogr Sci 2011;21:489-502. https://doi.org/10.1007/s11442-011-0859-0.

[7] Muta'ali L. Teknik analisis regional: untuk perencanaan wilayah, tata ruang dan lingkungan. Yogyakarta: Badan Penerbit Fakultas Geografi (BPFG) UGM; 2015.

[8] Raghav. 4 Important Measures of Transport Networks (With Diagram). Geogr Notes 
n.d.

[9] Pratama AF, Suhendi A. 12 BUMN Kerjasama Kembangkan Pariwisata Joglosemar. WwwTribunnewsCom 2016.

[10] Kementerian Perhubungan. Dorong Pariwisata Joglosemar, Menhub Kebut Aksesibilitas Transportasi Jateng dan DIY. DephubGold 2019.

[11] Kurniadhini F. Tingkat Kesesuaian Lokasi Stasiun Bike-sharing Berdasarkan Preferensi Pengguna di Kota Yogyakarta. Tesis S2 Universitas Gadjah Mada, 2019.

[12] Saaty TL. Decision making with the Analytic Hierarchy Process. Sci Iran 2002;9:215-29. https://doi.org/10.1504/IJSSCI.2008.017590.

[13] ArcGIS Pro 2.8. Understanding density analysis. ProArcgisCom n.d.

[14] Gudono. Analisis Data Multivariat. Yogyakarta: Badan Penerbit Fakultas Ekonomi (BPFE) UGM; 2011.

[15] Hair JF, Babin BJ, Anderson RE, Black WC. Multivariate Data Analysis (Seventh Edition). London: Pearson Education Limited; 2014.

[16] OECD. Handbook on Constructing Composite Indicators: Methodology and User Guide. Denmark: OECD Organisation for Economic Co-operation and Development; 2008. https://doi.org/10.1111/jgs.13392.

[17] De-Smith DMJ, Goodchild MF, Longley PA. Geospatial Analysis (6th Edition). United Kingdom: The Winchelsea 2018. https://doi.org/10.1080/00045600802708705. 